\title{
In het teken van Kaïn. Een theologische exegese van Genesis 4
}

H G L Peels ${ }^{1}$

(Theologische Universiteit, Apeldoorn)

\section{ABSTRACT}

\section{In the sign of Cain. A theological exegesis of Genesis $\mathbf{4}$}

Present day reflection upon the burning questions of evil an violence increasingly dominate the agenda of modern society. Biblical scholarship can contribute meaningfully to this discourse by analysing biblical narratives in which the themes of violence and animocity occur. In this regard it becomes necessary to unmask the mechanisms of violence, and to examine the judgement of violence from a biblical-theological perspective. Violence and animocity are displayed very soon in the Old Testament. Genesis 4 recounts the well-known story of Cain and Abel. The story of the world's first children turns out to be the story of the world's firs murder. $Y H W H$ 's role in this process is of particular interest: his warnings (vss 6-7), his interrogation (vss 9-10), his sentence (vss 11-12) and his promise (vs 15). This article investigates Genesis 4:1-16 and focuses especially on the remarkable promise to Cain, the nature of Cain's mark (vs 15) and the theological significance of YHWH as the keeper of Abel's brother. Genesis 4 turns out to be a chapter with paradigmatic value for today.

\section{TER INLEIDING}

Sinds enkele jaren staat het geweldthema hoog bovenaan op de politieke, sociale en religieuze agenda van de moderne samenleving. Terwijl de alfawetenschappen de relatie tussen religie en geweld in korte tijd tot een spannend object van onderzoek hebben gemaakt, worden in de media en de publieke opinie zonder veel plichtplegingen soms snelle lijnen getrokken tussen monotheïsme en intolerantie, geloof en geweldpleging. Drie wereldgodsdiensten beroepen zich op het Oude Testament: jodendom, christendom en islam. Geen van deze drie "abrahamitische" godsdiensten kent een

1 Navorsingsgenoot Departement Oude Testament, Faculteit Theologie, Universiteit Vrystaat. Dit artikel bevat de bewerking van een rede die in verkorte vorm werd uitgesproken tijdens de opening van het academisch jaar 2005-2006 aan de Theologische Universiteit te Apeldoorn, Nederland. 
geschiedenis, die wat betreft agressie en geweld smetteloos genoemd kan worden - integendeel. Niet onbegrijpelijk, dat geregeld een beschuldigende vinger richting het Oude Testament gaat: ligt dáár niet de bron van veel ellende? Het Oude Testament als springader van een eindeloze geschiedenis van geweld?

Voor de gemiddelde bijbellezer is het een onthutsende ervaring om te ontdekken dat het meest prominente antropologische thema in het Oude Testament dat van het geweld is (Schwager 1978:58). Dit alles stelt de exegese en de bijbelse theologie vandaag voor een zeer bijzondere opgave. Hoe komt in het Oude Testament geweld ter sprake? Deze urgente kwestie regardeert uiteraard ook de moraliteit en het godsbeeld van het Oude Testament, en is theologisch van groot gewicht. Het behoeft geen betoog dat een zorgvuldige exegetische analyse en theologische evaluatie van de relevante tekstpassages een conditio sine qua non is voor elke serieuze poging om de vragen in het geding van een evenwichtig antwoord te voorzien. In deze studie wil ik hieraan een bijdrage leveren door de genoemde vraagstelling toe te passen op het bekende verhaal van Kaïn en Abel in Genesis 4:1-16. Deze tekst kan van vitaal belang zijn voor ons verstaan van het geweldthema in het Oude Testament, omdat hier voor de eerste maal in de Bijbel van geweld sprake is (McEntire 1999:18).

$\mathrm{Na}$ zijn verdrijving uit de hof van Eden en de directe nabijheid van God manifesteert de mens zich als potentieel gewelddadig. Dit geweld neemt direct de ergste vorm aan, die van fratricide (Wright 2004:215-216). De dood doet zijn intrede in de schepping. Via de dialogen tussen God en Kaïn komt het geweld met wortel en tak zozeer voor het voetlicht, dat deze perikoop als geheel een paradigmatische functie krijgt. Mijn analyse hiervan richt zich met name op de vraag naar de implicaties voor het godsbeeld: hoe verhoudt God zich tot het geweld van de mens, volgens de auteur van Genesis 4 ?

In het vervolg van dit onderzoek schets ik eerst de contouren van de bijzondere plaats, de aard en de structuur van Genesis 4:1-16. Daarna loop ik de tekst langs om een hoofdlijn van uitleg vast te stellen, waarbij ik apart stilsta bij de vraag naar de zin van het "teken van Kaïn". De exegese mondt uit in een ethische en theologische waardering van het geweldthema in deze perikoop. De aldus bereikte conclusies zal ik tenslotte onder spanning zetten met de vraag, of de 
geweldspiraal in Genesis 4 niet in zekere zin door God zelf in gang wordt gezet, en dit caput ons dus confronteert met een arbitrair godsbeeld.

\section{GENESIS 4 ALS DEEL VAN DE OERGESCHIEDENIS}

Niet alleen bevat Genesis 4 de eerste beschrijving van het fenomeen van menselijk geweld in het Oude Testament, maar ook biedt dit hoofdstuk een exemplarische beschrijving hiervan. Dit laatste hangt nauw samen met de positie van Genesis 4 in zijn literaire en canonieke context. Het boek Genesis is in zijn huidige vorm als een eenheid gestructureerd met behulp van de zogenaamde tôledôtformule "dit is de geschiedenis van...". Deze formule komt elf maal voor (Jacob 2000:71-79; Deurloo 1998:9-15), op één keer na steeds met de genitief van de voorvader, en gevolgd door een genealogie of een narratieve geschiedenis. De enige uitzondering is Genesis 2:4 "Dit is de geschiedenis van de hemel en de aarde." Hoewel door de afwijkende formulering ook een link wordt gelegd met het inleidende gedeelte Genesis 1:1-2:3, dient de formule hier zoals elders als opschrift voor de volgende sectie gelezen te worden (Wenham 1987:55-57).

Tussen het verhaal van de schepping van hemel en aarde in Genesis 1 en de geschiedenis van de ontwikkeling van de mensheid in Genesis 5 e.v. vormt Genesis 2-4 een redactionele eenheid met een eigen opschrift en een eigen intentie. De feitelijke genealogie van Adam begint pas met de tôledôt-formule in Genesis 5:1, maar daaraan voorafgaand biedt de bijbelse auteur in de separate sectie Genesis 2:4-4:26 onder de tôledôt van hemel en aarde (2:4) als het ware een theologische antropologie. Hier worden de relationele grondpatronen beschreven: tussen de mens en God, de mens en zijn medemens, de mens en de aarde. Na de schepping van de mens (Gen. 2) volgt in eerste generatie de breuk met God (Gen. 3) en in tweede generatie de breuk met de medemens (Gen. 4). Tot in detail zijn Genesis 3 en Genesis 4 op elkaar afgestemd: structureel, thematisch, literair, idiomatisch (Hauser 1980). Terecht hebben exegeten op grond van deze parallellie erop gewezen dat beide capita niet alleen na elkaar maar ook naast elkaar dienen te worden gelezen (Westermann 1978:75; Deurloo 1988:100-102). Toch is Genesis 4 meer dan de sociale keerzijde van de religieuze zondeval in Genesis 3, omdat nu een duidelijke progressie in de zonde en de vervreemding zichtbaar wordt (Von Rad 1961:157-164). 
In Genesis 2:4-4:26 komen de grote vragen van de mensheid aan bod: leven en dood, arbeid, sexualiteit en geweld, sterk en zwak. Familiegeschiedenis en wereldgeschiedenis vloeien ineen, waar de narratief over het begin van de menselijke cultuur de prototypen ook als archetypen ziet. Hier worden reële individuen uit de oergeschiedenis beschreven, wier woorden en daden echter van betekenis zijn voor de gehele mensheid en grondpatronen van het menselijk leven weerspiegelen (Wenham 1987:117). Daarom gaat het in Genesis 4 om meer dan de particulariteit van een geweldpleging, het gaat vooral ook over de universaliteit van het geweld.

\section{AARD EN STRUCTUUR VAN GENESIS 4:1-16}

In vrijwel elke studie over Genesis 4:1-16 kan men de opmerking aantreffen dat dit gedeelte de exegeet voor puzzels stelt, omdat zoveel onuitgesproken blijft. De plot is wel duidelijk, maar de lacunes in het verhaal geven aanleiding tot allerlei detailvragen en speculatie: waarom Kaïn het initiatief neemt tot het brengen van een offer, waarom zijn offer niet geaccepteerd wordt, hoe hij dit te weten komt, wat hij tegen zijn broer zegt, voor wie hij bang is, etc. De receptiegeschiedenis van Genesis 4 vertoont dan ook een bont palet van uitleg, te beginnen bij de pogingen van de versiones om de lacunes op te vullen en onduidelijkheden weg te werken (Quinones 1991; Goosen 1990; Zuurmond 1982).

In een oudere fase van het wetenschappelijke bijbelonderzoek werd ter verklaring van de incongruenties van de tekst veel aandacht gegeven aan de reconstructie van veronderstelde Vorlagen, met universele verhaalmotieven als de broederstrijd, de rivaliteit tussen de beroepen van herder en landbouwer, of de spanning tussen cultuurland en nomadendom. Lange tijd was overheersend de visie van B. Stade en J. Wellhausen, die Genesis 4 verklaarden als een etiologie van de Kenieten, met Kaïn als stamvader. Met name sinds de grote commentaren van U Cassuto (1961-1964) en C Westermann (1974) heeft men echter deze lijn van de kollektivstammesgeschichtlichte verklaring als inadequaat beoordeeld en geeft men de voorkeur aan de individual-urgeschichtliche uitleg, hoewel een enkeling vasthoudt aan de oude uitleg (Dietrich 1977; Seebass 1996). Het moderne literair-synchrone onderzoek pleit met reden voor de originele eenheid van de tekst (Mathews 2001:260264). Deze maakt een coherente uitleg mogelijk, hoewel vraagtekens 
blijven, zowel door de elliptische verhaalstijl als vanwege het voorkomen van exegetische cruces (bijvoorbeeld in vs 1 en vs 7).

Genesis 4 vertoont een duidelijke interne samenhang via de vermeldingen van gemeenschap, zwangerschap en geboorte in vss 1, 17 en 25, de reprise van vs 15 in vs 24, en de inclusio van het aanroepen van de naam van YHWH in vss 1 en 26. Tegelijk vormt de perikoop van vss 1-16 een afgeronde eenheid met een eigen plot, openend met de vermelding van Kaïns opkomst "met YHWH" (vs 1) en Kaïns ondergang "weg van het aangezicht van YHWH" (vs 16). De teksteenheid zelf bestaat uit een afwisseling van narratief en dialoog: 1-5 introductie; 6-7 eerste dialoog; 8 geweldpleging; 9-15a tweede dialoog; 15b-16 afsluiting. Wat opvalt is dat de narratief beknopt is, terwijl het volle accent valt ligt op de dialogen (Cassuto 1961:183-184; Van Wolde 1999:36).

\section{LEZING VAN DE TEKST}

\subsection{Eerste scène: introductie en offergave (4:1-5)}

Het eerste vers van Genesis 4 linkt dit hoofdstuk met het voorgaande. De vreugderoep van Eva bij de geboorte van Kaïn: "Ik heb een "man" ('îs) verkregen" is veelzeggend: het gaat om de tweede generatie van de mensheid, die nu buiten de hof van Eden een bestaan moet opbouwen. Hoewel door God verdreven, is de mens niet zonder God: Eva roemt dat zij Kaïn "met" ('èt) YHWH heeft verkregen. Over de precieze betekenis van deze prepositie in dit verband bestaat onzekerheid (Westermann 1974:396-397), maar hiermee lijkt toch een positieve gedachte aangegeven te worden: YHWH als de gever van vruchtbaarheid maakt het leven mogelijk, ondanks de dreiging van de dood (cf. 2:17). Door de populairetymologische woordspeling met het verbum qnh klinkt in de naamgeving van Kaïn (qayin) mee, dat hij een voortbrengsel/schepsel in relatie tot YHWH is (Deurloo 1998:58; Becking 1995b:343-344).

De wijze waarop Kaïn en Abel in deze eerste sectie van Genesis 4 worden geïntroduceerd, is veelzeggend. Kaïn als eerste, begeleid door de vreugderoep van zijn moeder, die hem in relatie tot de zegen van YHWH stelt. Zonder vreugderoep komt als tweede Abel ter wereld, die nog voordat zijn naam klinkt reeds als "Kaïns broer" wordt getypeerd (vs 2). Waar Abel schaapherder wordt, treedt Kaïn als oudste en eerste in de voetsporen van zijn vader: hij wordt landbouwer (cf. 3:17-19, 23). De naam Abel (hèvèl) betekent 
"zucht', "ademtocht" (Becking 1995a:3-4) - hij figureert slechts als het tegenbeeld, de zwakke evenknie, die nauwelijks een eigen geschiedenis krijgt. Kaïn speelt de hoofdrol, Abel een verdwijnende bijrol.

Het initiatief tot het brengen van een offergave (minchäh) aan God komt van Kaïn (vs 3), die hierin door zijn broer Abel wordt gevolgd (vs 4). Het materiaal ligt in de lijn van hun respectievelijke beroep, wel wordt de gave van Abel uitgebreider beschreven dan die van Kaïn (zie verder onder $\S 7$ ). Reden noch achtergrond van deze "offercultus" wordt vermeld. Even bondig is de vermelding van de goddelijke reactie: Abel en zijn offer ziet YHWH aan, Kaïn en zijn offer ziet YHWH niet aan (vs 5). De woordvolgorde verplaatst de aandacht van het offer naar de persoon - om Kaïn zelf zal het gaan. Ook de vraag hoe de beide broers YHWHs reactie hebben vernomen blijft buiten beeld. De tekst zoomt ogenblikkelijk in op de persoon van Kaïn. Hij ontsteekt in hevige woede (chārāh $\left.m^{e} o d\right)$ wat uiterlijk ook zichtbaar wordt: zijn aangezicht "valt" (vs 5b, cf. Jer 3:12). Dit soort woede kan het voorspel van moord worden (Gen 34:7; 1 Sam 18:8; Neh. 4:1 - mede gelet op deze parallellen, is de interpretatie van nfl pānîm als aanduiding van een vorm van neerslachtigheid af te wijzen, contra Gruber 1980:35-36 en Hamilton 1990:224).

\subsection{Eerste dialoog (4:6-7)}

De eerste dialoog opent in 4:6-7 met een aantal vragen van YHWH aan het adres van Kaïn, net zoals dat in de tweede dialoog (4:9-15a) zal gebeuren (Craig 1999). YHWH die Kaïns offer niet aannam, heeft Kaïn zelf niet laten vallen. De aanleiding tot deze interventie werd in vs 5b gegeven: de grote toorn van Kaïn. YHWH is blijkbaar op de hoogte van Kaïns verborgen motieven en gevoelens, en stelt deze in het licht van "goeddoen" of "niet goeddoen" (yț). Helaas is vs 7 een berucht cryptische tekst, zowel in syntactisch als in exegetisch opzicht, waarvan de uitleg niet anders dan tentatief kan zijn.

Het minst moeilijk is vs 7a: tegenover het "vallen" ( $n f l)$ van het aangezicht stelt God het "opheffen" (nś) van het aangezicht. Kaïn heeft geen reden om een grote woede te voeden, als hij góeddoet. Impliciet wordt hiermee Kaïns gedrag als niet goed gekarakteriseerd: hij heeft zich op een verkeerde weg begeven. YHWH waarschuwt hem om niet op die weg voort te gaan. De reden hiervan ligt in het gevaar van de "zonde" die om zich heen dreigt te grijpen (vs 7b). 
Voor de eerste maal valt in het Oude Testament het woord "zonde" (chatțât), en wel op het cruciale moment dat een verstoring van de intermenselijke relaties tot geweld kan gaan leiden.

Het is niet geheel duidelijk op welke wijze de zonde hier ter sprake komt. De meeste exegeten interpreteren de tekst als een verwijzing naar de dreigende macht van de zonde, die haast demonisch poogt Kaïn in haar macht te krijgen (Westermann 1974:407-410; Wenham 1987:106). Of bevat deze tekst de gedachte dat zijn broer Abel voor Kaïn de "deur" in de zin van "toegang/aanleiding" tot de zonde is (Janowski 2003)? Of is de voorstelling dat Kaïn zelf, als hij niet goed handelt, aan de deur van de zonde ligt (Deurloo 1967:103-107; Deurloo 1998:59-60). Weer anders is de mening dat het participium rōbesş een nadere uitleg biedt van de "zonde': "there is at the door sin, (namely) being on the lurk' (Van Wolde 1991:31-32). Ook ten aanzien van het slot van vs 7 gaan de meningen uiteen, ofschoon de meeste exegeten van mening zijn dat hier sprake is van de "begeerte" van de zondemacht die naar Kaïn uitgaat, en die hij in toom moet houden. Een andere uitleg verdisconteert de parallellie tussen $4: 7 \mathrm{~b}$ en $3: 16$, en stelt dat het hier gaat om de gerichtheid van Abel op Kaïn, en Kaïns roeping om zijn leidinggevende positie als eerstgeborene ten aanzien van zijn broer weer in te nemen (Deurloo 1967:108-112; Deurloo 1998:60; Janowski 2003:149).

Ondanks exegetische onzekerheden, is de betekenis van deze dialoog voor ons onderzoek niet onduidelijk. De wortels van het geweld dat in het vervolg van de tekst aan de oppervlakte komt, worden hier reeds blootgelegd: de toorn die een wereld van emoties bevat, het afbreken van de communicatie ('gevallen aangezicht'), gevolg van het "níet goed" handelen. Het kwaad dat Kaïn dreigt te ondernemen is niet een noodlot, maar een zondemacht die hij moet en blijkbaar ook kán - tegengaan. De wijze waarop YHWH sprekend wordt ingevoerd is veelzeggend: Hij intervenieert en stelt Kaïn voor de keuze, Hij appelleert en waarschuwt. De teneur van deze dialoog is evident dat YHWH de mens van het kwaad van het geweld wil afhouden.

\subsection{Tweede scène: de daad $(4: 8)$}

Het frappeert de lezer dat de eerste dialoog afgebroken wordt: Kaïn geeft geen antwoord. Als hij wel spreekt, is het tot zijn broer Abel (vs 8). De tekst vermeldt niet wat Kaïn heeft gezegd. Sommige 
uitleggers maken van deze nood een deugd en menen dat deze stilte sprekend is, een bewijs dat Kaïn het bestaan van die ander, zijn broer, als zijns gelijke ontkent (Van Wolde 1991:35; McEntire 1999:23). Hoe het ook zij, uiterst bondig wordt verhaald hoe de mens, die nu voor het eerst voor de keuze tussen goed en kwaad gesteld werd (cf. 2:17; 3:5,22), voor het kwade kiest. Een nadere motivatie ontbreekt. De beknoptheid van deze tekst die in het centrum van de hele perikoop staat, suggereert iets van het eruptieve en irrationele van het geweld. Zowel het feit dat de daad in "het veld" plaatsvindt (cf. Dtn 22:25) als de formulering dat Kaïn tegen zijn broer "opstaat" (qûm, cf. Dtn 19:11) duidt op een bewuste daad. Kaïn is de eerste mensenmoordenaar in de geschiedenis.

\subsection{Tweede dialoog (4:9-15a)}

De tweede dialoog vindt plaats in de taalvormen van een rechtsgeding: beschuldiging en aanklacht, onderzoek en ontkenning, vloek en straf (Brueggemann 1982:60). Dit gehele gedeelte wordt gekenmerkt door een juridisch coloriet. YHWH treedt op als rechter, die opkomt voor wie geen stem meer heeft. Wie met geweld het leven van de broeder aantast, heeft niet alleen met die ander van doen, maar ook met YHWH. Hij roept Kaïn ter verantwoording, maar Kaïn verwerpt elke verantwoordelijkheid (vs 9). Kaïns antwoord toont hoe in het kielzog van geweld andere verschijnselen die de samenleving aantasten meekomen: de leugen ("ik weet het niet") en de brutale ontkenning van de zorg voor de broeder ("ben ik mijn broeders hoeder?"). De moord in het verborgene gepleegd kan echter niet verborgen blijven. Waar Abels stem voorgoed zwijgt, schreeuwt zijn bloed naar de hemel om recht ( $s^{c} q$ : de "Zeterruf"). Hierbij behoeft niet specifiek de notie van de bloedwraak in het geding te zijn, het gaat meer algemeen om het rechterlijk handelen van YHWH (Peels 1995:67-69). In vs 10 ligt een gedachte die in het Oude Testament veelvuldig verwoord wordt: YHWH als de beschermer van wat zwak en gering is, de rechter die het voor de slachtoffers opneemt (Wenham 1987:107; Peels 1995:290-292).

Als de Rechter in vss 11-12 zijn oordeel velt en de schuldige straft, gebeurt dit in de vorm van een vloek, waarin het voor Genesis 2-4 zo belangrijke " "da $\bar{a} m \bar{a} h$-motief nadrukkelijk verwerkt wordt. Waar in Genesis 3 de aardbodem vervloekt werd omwille van de mens, wordt in Genesis 4 de mens vervloekt vanuit de aardbodem. Van de aardbodem die het bloed van zijn broeder heeft ontvangen, 
zal Kaïn niets meer ontvangen (Deurloo 1967:119-120; Spina $1992)^{2}$. Op één dag wordt Kaïn "Gottlos - Heimatlos - Brotlos" (H. Frey). Hij zal een permanente vluchteling en zwerver worden ( $n \bar{a}$ ", wānād, vs 12) in het land nôd (vs 16). Wie zijn broer doodt zal zonder broeders moeten leven. Op de achtergrond van deze woorden ligt het fenomeen van de "Friedloslegung', de verdrijving uit de familiekring die in een stammengemeenschap het lot was van hen, die een bloedverwant hadden gedood (Peels 1995:68; Wenham 1987:108). Door geweld wordt een mens tot een zwerver gemaakt, en worden alle banden die het leven vreugde, zin en doel geven verbroken.

Dan klinkt in vss 13-14 Kaïns stem, in een diepe klacht. Leven in eenzaamheid als een outlaw, zonder beschermming, is verschrikkelijk (cf. Job 15:22f., 18:18-21, 30:3-8). Bij zijn dood zou niemand een traan laten. Als Kaïn in vs 14 zijn straf specificeert, klinkt hierin de echo mee van Genesis 3:24 - YHWH verdreef ( $g r s$ ) de mens uit de hof van Eden, Kaïn wordt nog verder weg verdreven. De vertaling van vs 13 heeft veel discussie losgemaakt. Vanwege de ambivalente semantische waarde van het woord ${ }^{c} \bar{a} w o ̂ n$ kan de door Kaïn gebruikte uitdrukking $n s{ }^{\prime}$ ' $\bar{a} w o ̂ n$ (letterlijk: ongerechtigheid/ straf dragen) op twee manier opgevat en vertaald worden: zowel "mijn zonde is te groot om vergeven te worden" als "mijn straf is te groot om te dragen" (Koch 1986:1165). De eerste vertaling zou kunnen leiden tot de conclusie dat Kaïn uiteindelijk schuld bekent en impliciet enige spijt toont. Hoewel in het Hebreeuws de noties van schuld en straf moeilijk te scheiden zijn, menen echter de meeste exegeten terecht, dat de tweede vertaling de voorkeur verdient. Nergens in Genesis 4 treffen we enig signaal aan van berouw of schuldbelijdenis aan de kant van Kaïn, integendeel (Gowan 1988:51; Hamilton 1990:233; Mathews 2001:233; Westermann 1974:420). Direct al in vs 14 klaagt Kaïn uitsluitend over de zwaarte van de straf. Zo bevat vs 13 geen spoor van berouw, maar wel van zelfmedelijden en wrok. Kaïns antwoord is niet een verzoek maar een protest. De moordenaar is bang vermoord te worden.

Hierop inhakend, is het laatste woord in deze dialoog aan YHWH: "Geenszins, ieder die Kaïn doodt, moet weten: hij zal

2 "Den Acker hat Qain bebaut, des Ackers Früchte dargebracht, dem Acker Bruderblut zu trinken gegeben: aber vom Acker her klagt das Blut wider ihn, darum verweigert der Acker ihm seine Frucht, so wird er vom Acker verbannt" (Gunkel 1902:39). 
zevenvoudig gewroken worden!" (vs 15a) (Peels 1995:62). Deze woorden, die een plechtige algemene rechtsuitspraak vormen (Liedke 1971:124,143; Westermann 1974:423-424), brengen een onverwachte wending in het verhaal aan: zelfs de broedermoordenaar wordt onder goddelijke protectie gesteld. De wraak voor Kaïns dood zal "zevenvoudig" zijn: een vol getal als aanduiding van verhoogde intensiteit (cf. Ps 12:7; Spr 6:31; Dan 3:19 en vooral Ps 79:12 (cf. vs 10). Kaïns leven wordt "zevenvoudig" gegarandeerd, met andere woorden: compleet (Otto 1993:1014).

\subsection{Derde scène: de afloop (4:15b-16)}

De goddelijke belofte van rechtsbescherming wordt als het ware sacramenteel met een teken aan/voor Kaïn bevestigd. Aan het Kaïnsteken wijd ik onder $\S 5$ een separate bespreking. In vs 16 wordt de afloop van de geschiedenis verhaald: Kaïn vertrekt, weg van het aangezicht van YHWH. Het verhaal begon met het "vallen" van Kaïns aangezicht (vs 5), een bewuste communicatiebreuk die via de acte van geweld uitloopt op een leven ver van Gods aangezicht. De landbouwer van het begin is nu een zwerver geworden: zonder ouders, zonder broer, zonder land, zonder God. Geweld tast ook de eigen identiteit aan. Het oordeel van YHWH wordt onverwijld uitgevoerd: Kaïn is nu een $n \bar{a} d$ (vs 12) in the land nôd (vs 16). Dit land wordt nader gekwalificeerd met de woorden "ten oosten van de hof van Eden', dezelfde zinsnede als in 3:24. De mens die geweld verkoos, komt al verder bij God vandaan te staan (Gordon 2004:2024; Görg 1994).

\section{HET KAÏNSTEKEN (GENESIS 4:15B)}

Wellicht het meest verrassende element in de hele perikoop van Genesis 4:1-16 is de wending aan het slot, als de zojuist door God met een ernstige vloek gestrafte broedermoordenaar de belofte van Gods bescherming ontvangt. YHWH wil de hoeder zijn van de man die zijn broeders hoeder niet wilde zijn. Het is voor iedere bijbelwetenschapper duidelijk dat het teken van Kaïn, in tegenstelling tot de lading die de volksmond hieraan toekende, niet een brandmerk of schandvlek aanduidt. In de context van Genesis 4 gaat het duidelijk over een teken dat potentiële bedreigers afschrikt, en dus bescherming biedt. Maar veel verder gaat de eensgezindheid onder de exegeten niet. Over de vraag aan wat voor teken gedacht moet worden, gaan de meningen ver uiteen (Mellinkoff 1981; Deurloo 1967:24-29; Westermann 1974:424-427). 
De meeste uitleggers gaan ervanuit, dat het teken ('ôt) door YHWH op een of andere wijze aan Kaïn zelf is aangebracht (sîm $l^{e}$ ), daarbij wijzend op parallellen in Exodus 12:13 (het bloed aan de deurposten), Ezechiël 9:4 (een merkteken op de voorhoofden van hen die Jeruzalems gruwelen afwijzen), of Op. 7: 9 (de knechten van God aan het voorhoofd verzegeld, cf. 14:9, het merkteken van het beest op voorhoofd of hand). Daarbij zijn twee lijnen van uitleg aan te wijzen: de collectieve en de individuele uitleg. De collectieve uitleg, die in het oudere onderzoek overheersend was, zag Kaïn als stamvader van de Kenieten of als representant van het nomadische leven. Zo kon het Kaïnsteken verklaard worden als het stamteken van de Kenieten, dat hen merkte als YHWH-vereerders. Soms werd dit nog nader ingevuld: het Kaïnsteken was de eerste letter van de godsnaam YHWH, op het voorhoofd afgedrukt, of vormde het beroepsteken van de smeden. Minder specifiek is de gedachte, dat het een tatoeëring betrof, als merkteken van een nomadenstam ${ }^{3}$. Vandaag de dag zijn dit soort opvattingen vrijwel verlaten, nu de meeste exegeten zijn teruggekeerd naar de individuele uitleg van het Kaïnsverhaal. Vele suggesties zijn in deze lijn gedaan om het Kaïnsteken te identificeren: melaatsheid, een hoorn op het voorhoofd, een zwarte huid, een verwilderd uiterlijk, een brandmerk in het gezicht, een tattoo, een specifieke haarstijl, etc. Inventief is de joodse traditie die het "teken" uitlegde als een hond, die Kaïn begeleidde ter afschrikking van diens vijanden (Jacob 2000:146). Weer een andere gedachte is dat Kaïns eigen naam het teken is, vanwege de klankcombinatie van qayin en yuqqam ('hij zal gewroken worden') (Wenham 1987:109-110).

Een geheel andere lijn van uitleg is dat het niet om een teken aan Kaïn (een 'Schutzzeichen') gaat, maar om een teken voor Kaïn (een 'Beglaubigungszeichen'). YHWH zou Kaïn een bijzonder openbaringsteken hebben gegeven, ter bevestiging van zijn toezegging van rechtsbescherming, bijvoorbeeld een donderslag - te vergelijken met de functie van de regenboog in Genesis 9:16. Deze uitleg heeft echter maar weinig bijval gekregen, omdat de context van het Kaïnsteken té duidelijk spreekt over afschrikking van potentiële vijanden.

3 Een recente variant daarvan is de suggestie dat het om een soort veldteken ging (cf. Ps 74:4), dat Kaïn zelf kon oprichten (Seebass 1996:159). 
De conclusie is onvermijdelijk dat de vraag naar de precieze inhoud en vorm van het Kaïnsteken nog nimmer een bevredigend antwoord heeft gekregen. Deze vraag is gelet op de narratieve condensatie van dit strak opgebouwde elliptische geschiedverhaal in feite ook niet echt relevant. Wat veeleer van belang is, is de vraag naar de eigenlijke intentie van de verlening van het Kaïnsteken. Ook op dit punt tekenen zich twee lijnen af.

Volgens de eerste lijn van uitleg betekent het Kaïnsteken een aanscherping of verzwaring van de straf (Procksch 1913:48). Kaïn zal het volle pond van zijn straf moeten dragen. Door dit teken wil YHWH voorkomen, dat er voortijdig in de strafvoltrekking wordt ingegrepen. Een vroegtijdige dood zou immers afdoen aan de zwaarte van het oordeel. Het probleem met deze uitleg is echter dat de aansluiting van vs 15 aan het voorgaande vers niet voldoende verdisconteerd wordt: Kaïn klaagt over zijn harde lot, culminerend in de vaststelling dat hij als vogelvrije willekeurig afgemaakt kan worden. Híerop is het teken dat YHWH hem geeft een antwoord. Bovendien wijst ook de structurele parallelie met Genesis 3 een andere kant op. In Genesis 3:21 wordt verhaald hoe YHWH, na de veroordeling en vervloeking van de mens maar nog vóór diens verdrijving $(g r s)$, kleren voor hem maakt. Dit suggereert dat ook het teken van Kaïn, ná diens veroordeling en vervloeking maar nog vóór zijn verdrijving, een positieve functie heeft. Maar welke?

Volgens de tweede lijn van uitleg is de verlening van het Kaïnsteken een bewijs van strafvermíndering. Vaak wordt dit gekoppeld aan een interpretatie van vs 13 als blijk van Kaïns spijt of tenminste een schuldbekentenis; YHWH zou Kaïn daarom nu tegemoet komen met zijn bescherming. Nu heeft deze exegese van vss 13-14 niet veel vóór; bij nader toezien geven deze verzen juist blijk van een verharding aan Kaïns zijde (zie boven bij 4.4). Dit laat echter de mogelijkheid onverlet dat in vs 15 YHWH met het Kaïnsteken toch een strafbeperking beoogt, om Kaïn het leven te gunnen. Is dit een teken van genade voor Kaïn? Op dit punt kunnen theologische beschouwingen een hoge vlucht nemen, en wordt soms welhaast een paulinische rechtvaardigingsleer in de tekst ingelezen: Genesis 4:15 zou het eerste signaal zijn van de iustificatio impii. Het is vooral $\mathrm{G}$ von $\mathrm{Rad}$, die met zijn heilshistorische visie op de ontwikkeling van zonde en vergeving in Genesis 1-11 aan deze gedachte heeft bijgedragen (Von Rad 1972:117; Preuss 1992:185, 
283). Terecht voorziet Golka deze visie van vraagtekens; van enige begenadiging van Kaïn valt niet te spreken (Golka 1980).

Als er al van genade gesproken moet worden, dan van common grace, en niet van particuliere genade voor Kaïn. Er is geen tegenspraak tussen de vloek over Kaïns leven en de wraak over Kaïns dood. Het teken van Kaïn intensiveert noch reduceert de uitvoering van het rechtoordeel. Waar het om gaat is bescherming voor de dood, de straf blijft onverminderd van kracht. De gestrafte moordenaar zal moeten leven ver bij God vandaan, maar nog niet onbereikbaar voor God. De zin van de rechtsbescherming via het Kaïnsteken zal in deze context geen andere zijn, dan dat YHWH hiermee de neerwaartse geweldspiraal een halt toeroept ${ }^{4}$. Het geweld dat in Genesis 4:1-16 groeit, dreigt te escaleren en ook anderen mee te slepen. YHWH stelt echter aan de geest van moordzucht grenzen: zie het teken van Kaïn! Fraai formuleert Von Rad: "Hier offenbart sich ein ordnender und bewahrender Gotteswille. Der in Kaïn ausgebrochenen Mordgeist soll sich nicht in immer weitere Kreise fortpflanzen, und die Strafe, die Gott über Kain verhängt hat, soll nicht zu einer Verwilderung der Menschen untereinander den Anlass geben" (Von Rad 1972:80; Mathews 2001:278; Mukenge 1999:427). Zelfs middenin zijn rechtvaardig gericht over de menselijke zonde komt YHWH tussenbeide om de mens te behoeden voor de ernstige gevolgen die zijn daden dreigen te teweeg te brengen.

In het vervolg van Genesis 4 komt het uitdijende karakter van het geweld duidelijk in beeld. De inperking van geweld door YHWH wordt in de lijn van het Kaïnsgeslacht nadrukkelijk doorbroken. Met een directe zinspeling op Gods woorden van rechtsbescherming aan Kaïn (vs 15) proclameert Lamech een grenzenloze conservatio sui in een wereld van geweld (vs 24): het kwaad treedt buiten alle oevers.

Ondertussen is duidelijk geworden dat YHWH een God is, die opkomt voor de slachtoffers van het kwade, en met zijn rechtshandelen aan de geweldenaar en zijn toezegging van een zevenvoudige vergelding aan het adres van potentiële moordenaars, ook zelf geëngageerd is in deze geschiedenis waarin zonde en

4 Ook elders in het Oude Testament wordt zorgvuldig omgegaan met de straf voor moordenaars. "God's protection of Cain belies an anxiety over the appropriate punishment of a killer, an issue taken up by other biblical texts" (Barmash 2005:19). 
onrecht het veld gingen beheersen. YHWH kan daarbij met geweld dreigen of zelf geweld gebruiken, om het kwade in te perken. Genesis 4 onthult daarom voor het eerst in de geschiedenis van de mensheid ook de mogelijkheid en het bestaan van tegengeweld, in dienst van het recht.

\section{GEWELD EN RECHT: EEN THEOLOGISCHE EVA- LUATIE}

Op basis van het voorgaande exegetische onderzoek kunnen we nu een aantal conclusies trekken ten aanzien van de waardering van het geweldthema en de implicaties hiervan voor het godsbeeld in Genesis 4:1-16.

Het bijbelverhaal van Kaïn en Abel weerspiegelt een hoog besef van moraliteit, in de afwijzing van geweld en de accentuering van de zorg voor de medemens. In dit caput is geen zweem van verheerlijking van geweld, zoals we dat elders in the literature of de Oriënt kunnen aantreffen (Smelik 2005). Daarentegen wordt hier het geweldmechanisme ontmaskerd en ethisch-theologisch aan de kaak gesteld. Zowel over de aard, de wortels als de gevolgen van het geweld biedt Genesis 4 fundamentele inzichten.

Van primair belang is het directe verband in dit tekstgedeelte tussen geweld en "zonde" (chațtât vs 5; "āwôn vs 13), een begrip dat opmerkelijkerwijs hier voor het eerst gebruikt wordt. Geweld wordt geschetst als een product en een manifestatie van de macht van het kwaad. De mens staat hier niet weerloos tegenover, hij moet deze dreiging onderkennen en tegengaan (vs $7 b$ ). Het feit echter dat de eerste de beste mens - zodra het menselijk geslacht zich buiten de hof gaat ontplooien - tot een gewelddaad komt is tekenend. Blijkbaar behoort dit tot het potentieel van de mens die ongehoorzaam werd tegenover zijn God. Zijn kennis van goed en kwaad brengt hem weinig goeds: bij de eerste de beste keer dat hij voor een keuze wordt gesteld (vs 7a), valt hij door de mand omdat hij het kwade kiest. Hij is van de oorsprong af geneigd níet naar God te luisteren (vs 6), geen verantwoording af te leggen (vs 9) en tot geweld zijn toevlucht te nemen (vs 8).

Naar zijn eigen aard is geweld de ontkenning en aantasting van de medemenselijkheid; de broedermoord is de oervorm van alle geweld. Tegelijk is er een diepere dimensie: geweld tegen de broeder kan niet als een intermenselijk gebeuren op zich worden afgedaan, maar regardeert God zelf, de Schepper van het leven (vss 1, 9-10). 
Daarom kan geweld ook nooit het laatste woord hebben (vs 10), omdat het de mens strafwaardig maakt. De dader wordt persoonlijk ter verantwoording geroepen voor zijn daden (vss 9-10). Geweld tendeert naar uitdijing en escalatie: in het kielzog van de gewelddaad manifesteren zich de leugen, de brutaliteit, de afwijzing van verantwoordelijkheid voor de ander (vs 9), het zelfbeklag en het protest tegen God (vss 13-14), en tenslotte de mogelijkheid van een nieuwe moord (vss 14-15, cf. vs 24). Waar het geweld buiten zijn oevers treedt en escaleert, kan alleen nog het tegengeweld van God de gevolgen indammen (vs 15).

De wortels van het menselijk geweld worden in de bijbelse narratief gelocaliseerd in het broeinest van troebele emoties. Het heeft weinig zin om achter de tekst naar diepere psychologische oorzaken van het geweld te zoeken: jaloezie, gekrenkte trots, etc. Het geweld tegen de broeder vloeit voort uit grote woede en boosheid, die de communicatie verbreekt (vs 5b). Deze riskante houding wordt gekarakteriseerd als een niet-goed-doen (vs 6). Hiermee hangt samen het eruptieve en irrationele van het geweld: het slaat plotsklaps en hevig toe (vs 8). Geweld is letterlijk onzinnig.

Niet minder onthullend verhaalt deze perikoop over de fatale gevolgen van het geweld. Geweld tast alle relaties aan die het leven goed en zinvol maken: met God, met de medemens, met de aarde, met zichzelf. Geweld brengt de mens in alle opzichten in een proces van vervreemding en isolement. Leven met geweld is leven onder de vloek. Geweld tegen het leven van de naaste keert zich tegen de geweldpleger zelf, omdat de God die het leven schiep daarover waakt en als rechter optreedt. Niet het geweld, maar de gerechtigheid zal het laatste woord hebben. Door geweld wordt de band met de medemens verbroken (vs 9). Wie zich aan geweld overgeeft, verliest ook de band met God (vs 14, 16). Zijn relatie met de schepping zelf raakt erdoor geschonden, de aarde zal niet langer bron van leven en vreugde voor hem zijn (vs 12). Ook de dader zelf verandert door zijn geweld: evenwicht en geborgenheid verdwijnen, het leven van deze mens wordt een vlucht (vss 12-16). Door geweld treedt een proces van verharding en vereenzaming in (vss 9, 14). De weg van ongehoorzaamheid aan God (vss 6-7), toegeven aan de zonde (vs 8) en weigeren van de verantwoordelijkheid (vs 9) is een alle opzichten doodlopende weg. 
Het geweld wordt ons in Genesis 4 getekend als de grote streep door de rekening van Gods goede schepping. Tegelijk wordt in Genesis 4, vooral in de dialogen, ook een tegenbeweging zichtbaar. Waar de mens voor de dood kiest, komt God voor het leven op; tegenover het geweld stelt God zijn recht. Niet alleen over het mechanisme van het menselijk geweld, maar ook over de houding van God daartegenover biedt het Kaïnsverhaal fundamentele inzichten. Te wijzen is op in elk geval de volgende drie elementen.

Sprekend is in de eerste plaats de dialoog in vss 6-7. Hier treedt YHWH op als een pastor, die weet wat er in de mens leeft. Met zijn vragen wil Hij Kaïn wakker schudden, en waarschuwt Hij hem voor wat dreigt. De intentie van deze dialoog is duidelijk deze, dat God de mens de goede kant wil opsturen, om het geweld te voorkomen. In de tweede plaats roept God na de moord de dader ter verantwoording, waarbij $\mathrm{Hij}$ optreedt in de functie van iudex supremus. Het kwaad kan niet verborgen blijven, God komt op voor de slachtoffers van geweld. Deze God is de laatste hoop voor alle monddood gemaakte hulpelozen in een wereld waar de machten van zonde, geweld en dood de dienst uitmaken. Hij is een Rechter die de mens verantwoordelijk stelt voor zijn daden. YHWH ontmaskert de leugens van de geweldenaar en spreekt vonnis over het kwaad van het geweld. Hij herstelt daarmee een grens die de mens doelbewust had geschonden: het schepsel heeft niet het recht om zich te vergrijpen aan het leven van de medemens. In de derde plaats damt God de gevolgen van het geweld in, door als protector zelfs van de dader te fungeren. Niet de vloek is Gods laatste woord, maar het teken dat Hij geeft aan de broedermoordenaar. De geest van moordzucht die in de mensheid om zich heengrijpt stuit hier op de grens die God stelt.

\section{EEN WILLEKEURIGE GOD IN GENESIS?}

De vraag kan gesteld worden, of het hiervoor geschetste beeld van YHWH als pastor, iudex en protector niet te positief gekleurd is, en of in Genesis 4:16 niet ook een andere, donkere, lijn zichtbaar wordt. Ontmoeten we hier niet ook een in wezen onberekenbare God, die uiteindelijk zélf de aanzet tot de geweldspiraal heeft gegeven, of althans daar mede verantwoordelijk voor is? In de belles lettres wordt soms gepleit voor een eerherstel van Kaïn. Heeft hij niet alle reden om boos te zijn? Hij is de eerstgeborene (vs 1), hij neemt het spontane initiatief tot het brengen van een geschenk (vs 3), niets lijkt 
erop te wijzen dat zijn offer minder is dan dat van Abel (vs 4), en toch wordt hij gepasseerd. Als YHWH later Kaïns geweld bestraft is dit terecht, maar is God hierin niet ook zélf betrokken, omdat hij door zijn selectieve voorkeur voor Abels offer aanleiding gaf tot animositeit bij Kaïn? Deze vraag wordt door een verwijzing naar Gods soevereine verkiezing (C Westermann, W Zimmerli, G von Rad) niet opgelost, maar des te dringender (Golka 1980:62; De Kruijf 2005). Een stap verder gaat W Brueggemann, die van mening is dat de traditionele uitleg van Genesis te hartvochtig over Kaïn en te vergoelijkend over YHWH spreekt. "The trouble comes not from Cain, but from Yahweh, the strange God of Israel. Inexplicably, Yahweh chooses - accepts and rejects (..) Essential to the plot is the capricious freedom of Yahweh' (Brueggemann 1982:56) . $^{5}$.

Veel hangt af van de juiste interpretatie van Genesis 4:3-5, de passage over de offers. De tekst zelf geeft niet rechtstreeks een uitleg van het feit dat God de offergave van Abel wel en die van Kaïn niet "aanzag". Waarom wordt Kaïns offergave niet aangenomen? Globaal genomen worden op deze vraag drie antwoorden gegeven.

De eerste verklaring neemt haar uitgangspunt juist in het ontbreken van een expliciete motivatie van Gods keuze. C Westermann is van deze lijn van uitleg de meest prominente vertegenwoordiger. Volgens hem komen we niet verder dan hier te spreken over Gods ondoorgrondelijkheid. Zo weerspiegelt het verhaal van Genesis 4 de werkelijkheid van het leven, met de ervaring van soms onverklaarbare zegen of tegenspoed, voorkeur en afkeur. "Es soll also gerade unerklärbar bleiben, warum Gott das Opfer des Abel ansieht und nicht das des Kaïn. Und dieses, will der Erzähler klar machen, ist eines der entscheidenden Konfliktmotive, wo immer es Brüder gibt' (Westermann 1974:405). Vaak wijst men er tevens op, dat in Genesis 4 voor het eerst het motief voorkomt dat in het boek Genesis een grote rol zal gaan spelen: de verkiezing van de jongste boven de oudste (Ismaël-Isaac; Esau-Jacob, Josef-Juda, etc.) (Deurloo 1967:101; Van Wolde 1991:29; Fox 1993). Inderdaad kan dit motief hier meespelen: YHWH doorbreekt de menselijke patronen van prioriteit en hiërarchie, en komt tegenover de "number

5 In zijn magnum opus uit 1997 werkt Brueggemann het thema van de ambiguïteit in het oudtestamentische godsbeeld breed uit, met een duidelijke voorkeur voor woorden als odd, unstable, unreliable, capricious, irascible, irrational, abusive (McEntire 1982:29-30; Peels 2006). 
one" die Kaïn is, op voor de zwakke Abel (hèbèl). Toch kan hiermee de verwerping van Kaïns gave niet geheel verklaard worden. De "jongste" speelt in Genesis 4 slechts een nevenrol, en verdwijnt al snel uit het verhaal, wat in alle andere gevallen van een goddelijke verkiezing van de jongste zeker niet het geval is.

Een tweede verklaring zoekt het motief in de aard van de offergaven zelf. Een al oude mening is, dat een bloedig offer God meer welgevallig zou zijn dan een graanoffer (Jacob 2000:137). Dit is in het licht van de oudtestamentische offerwetgeving echter moeilijk als doorslaggevend te beschouwen. Ook wordt wel de gedachte geopperd dat Kaïns offergave niet door God aangenomen wordt, omdat deze ontleend is aan de aardbodem ( $\left.{ }^{a} d \bar{a} m \bar{a} h\right)$ die juist door God was vervloekt (3:17) (Herion 1995; Spina 1992).

Een derde verklaring ziet de reden van de verwerping van Kaïns offergave in de attitude van de offeraar zelf. Zonder teveel te willen verklaren, zijn wij van mening dat deze laatste mening het meest recht doet aan de tekst. Hiervoor zijn vier argumenten aan te voeren:

a) In de beschrijving van de offergaven is er een duidelijke incongruentie. Bij Abels offer wordt breed beschreven hoe hij het beste van het beste brengt: de "firstborn" (bikkōrôt) en de vette delen. Kaïn brengt niet de bikkûrîm, maar slechts van de "vrucht" $\left(p^{e} r \hat{\imath}\right)$ van het land. Gelezen met de ogen van een joodse lezer, ligt hierin een duidelijke indicatie (Craig 1999:111-112).

b) In de context van de perikoop ligt het accent op een voortschrijdende verharding van Kaïn. Ook lijkt het moeilijke vs 7 te impliceren dat Kaïns gedrag vanaf het begin niet juist was. Het is niet toevallig dat in de formulering van Gods "aanzien" in vs 5 de persoon beide malen met name vóór het offer genoemd wordt.

c) Een onderzoek naar het motief van de verwerping van een offer, zowel in het Oude Testament als in Israëls Umwelt, brengt aan het licht dat de juiste instelling en gehoorzaamheid van de offeraar steeds van cruciaal belang zijn voor het al dan niet geaccepteerd worden van diens offers (De Moor 1975:223; Waltke 1986).

d) Ook een lezing in de bredere context van Genesis 2-11 pleit voor deze verklaring. Von $\mathrm{Rad}$ en anderen spreken terecht van een "Entwicklung bis hin zum vollendet Titanischen" in dit pars van Genesis (Von Rad 1961:164; Wenham 1987:1i). De auteur van deze 
hoofdstukken is een man geweest, aldus Vriezen, "die de diepte der zondigheid van het mensenhart volkomen heeft gepeild, en in de hele oerhistorie uitdrukking heeft gegeven aan zijn geestelijke overtuiging van de verdorvenheid van het menselijke geslacht" (Vriezen 1974:449). Het gaat met de mens van kwaad tot erger, en de suggestie van Genesis 4 is dat dit juist in de eerste vertegenwoordiger van een nieuwe generatie, een nieuwe 'àdām, aan de dag treedt.

Op deze wijze gelezen, past Genesis 4 naadloos in de opbouw van het boek Genesis. Voor de stoot tot het geweld, dat de schepping corrompeert en de vloek over de mens brengt, is niet een

willekeurige en onnaspeurbare God maar de mens zelf verantwoordelijk. Het is de mens die willens en wetens een dijkdoorbraak forceert. Tegelijk verhaalt Genesis 4 van YHWH die zijn wereld en mensheid niet overlaat aan de krachten van zonde en geweld: Hij waarschuwt, komt op voor slachtoffers, roept geweldenaars een halt toe en daagt hen voor de rechtbank, Hij straft en damt het geweld in.

In Genesis 4 is voor de eerste maal in het Oude Testament sprake van zonde en geweld, met als gevolg de ontheemding en het begin van het grote sterven. Dit is de introductie van een religieus boek dat onthutsend vol staat met geweldverhalen en geweldteksten, en het zicht opent op een wereld vol kwaad en animositeit. Hermeneutisch en theologisch is het niet indifferent dat in de canonieke eindredactie van het Oude Testament Genesis 4 deze fundamentele positie heeft gekregen, als de narratieve opmaat tot van wat de lezer verder heeft te verwachten. Hier wordt duidelijk wat in het hart van de mens leeft en wat God op het hart en in het oog heeft In het Oude Testament komt de lezer veel zaken tegen die hem verwarren of zelfs afschrikken, verhalen ook waarin hij soms de onbegrijpelijkheid van het werk van YHWH in deze wereld ontmoet. Maar helemaal aan het begin daarvan wordt door de plaatsing van Genesis 4 aangegeven, dat déze God in déze wereld tegenover alle geweld zijn recht en gerechtigheid stelt. Als een advocaat van slachtoffers en een rechter van daders, maar dan een rechter die ook pastor is, om deze wereld te bewaren voor de chaos.

\section{Literatuurverwijzingen}

Azevedo, J 1999. At the Door of Paradise. A Contextual Interpretation of Gen 4:7. BN 100, 45-59. 
Becking, B 1995. Art. Abel. DDD 3-4.

-, 1995. Art. Cain. DDD 343-344.

Brueggemann, W 1982. Genesis. Interpretation. Atlanta: John Knox.

-, 1997. Theology of the Old Testament. Testimony, Dispute, Advocacy. Minneapolis: Fortress.

Cassuto, U 1961. A Commentary on the Book of Genesis. Part I: From Adam to Noah: Genesis 1-6/8. Jerusalem: Magnes.

Childs, B S 1979. Introduction to the Old Testament as Scripture. London: SCM.

Craig, K M 1999. Questions Outside Eden (Genesis 4.1-16): Yahweh, Cain and Their Rhetorical Interchange. JSOT 86, 107-128.

De Kruijf, G G 2005. Give Place Unto Wrath!, in: Van Keulen, D \& M E Brinkman (eds.), Christian Faith and Violence. Volume 1 . Studies in Reformed Theology Volume 11h, 115-126. Zoetermeer: Meinema.

De Moor, J 1975. The Sacrifice Which is An Abomination To The Lord, in Van Es, H.M. (ed.), Loven en geloven. Festschrift N.H. Ridderbos, 211-226. Amsterdam: Bolland.

Deurloo, K 1988. De mens als raadsel en geheim. Verhalende antropologie in Genesis 2-4. Baarn: Ten Have.

-, 1998. Genesis. Kampen: Kok.

-, 1967. Kain en Abel. Onderzoek naar exegetische methode inzake een 'kleine literaire eenheid'in de Tenakh. Amsterdam: Ten Have.

Dietrich, W 1977. "Wo ist dein Bruder?" Zu Tradition und Intention von Genesis 4, in: Donner H, Hanhart R \& Smend R (eds.), Beiträge zur Alttestamentlichen Theologie. Festschrift W Zimmerli, 94-111. Göttingen: Vandenhoeck \& Ruprecht.

Fox, E 1993. Stalking the Younger Brother: Some Models For Understanding A Biblical Motif. JSOT 60, 45-68.

Golka, F W 1980. Keine Gnade für Kain, in: Albertz R et al (eds.). Werden und Wirken des Alten Testaments. Festschrift C Westermann, 58-73. Göttingen: Vandenhoeck \& Ruprecht.

Goosen, L 1990. Van Abraham tot Zacharia. Thema's uit het Oude Testament in religie, beeldende kunst, literatuur, muziek en theater. Nijmegen: SUN.

Gordon, R 2004. Holy Land, Holy City. Sacred Geography and the Interpretation of the Bible. Carlisle: Paternoster.

Görg, M 1994. Kain und das "Land Nod". BN 71, 5-12.

Gowan, D E 1988. From Eden to Babel. A Commentary on the book of Genesis 1-11 International Theological Commentary. Grand Rapids: Eermands.

Gruber, M I 1980. Was Cain Angry or Depressed? BAR 6, 35-36.

Gunkel, H 1902. Genesis. Handkommentar zum Alten Testament. Göttingen: Vandenhoeck \& Ruprecht. 
Hamilton, V 1990. The Book of Genesis. Chapters 1-17. New International Commentary on the Old Testament. Grand Rapids: Eerdmans.

Herion, G A 1995. Why God Rejected Cain's Offering: The Obvious Answer, in Beck A B et al. Fortunate The Eyes That See. Festschrift D. N. Freedman, 52-65. Grand Rapids: Eerdmans.

Hauser, A J 1980. Linguistic and Thematic Links between Genesis 4:1-16 and Genesis 2-3. JETS 23, 297-305.

Jacob, B 2000. Das Buch Genesis. Berlin: Schocken Verlag, 1934. Repr. Stuttgart: Calwer Verlag.

Janowski, B 2003. Jenseits von Eden. Gen 4,1-16 und die nichtpriesterliche Urgeschichte, in: Lange A, Lichtenberger H \& Detmard Römheld K F (Hrsg.), Die Dämonen Demons. Die Dämonologie der israelitisch-jüdischen und frühchristlichen Literatur im Kontext ihrer Umwelt, 137-159. Tübingen: Mohr.

Koch, K 1986. Art. ' ${ }^{c}$ âwôn. TWAT V, 1160-1177.

Liedke, G 1971. Gestalt und Bezeichnung alttestamentlicher Rechtssätze. Eine formgeschichtlich-terminologische Studie. WMANT 39. Neukirchen-Vluyn: Neukirchener.

Mathews, K A 2001. Genesis 1-11. New American Commentary. Nashville: Broadman \& Holman.

McEntire, M 1999. The Blood of Abel. The Violent Plot in the Hebrew Bible. Macon: Mercer University Press.

Mellinkoff, R 1981. The Mark of Cain. Berkeley: University of California Press.

Mukenge, A K 1999. Relecture de Gn 4,1-16 dans le contexte africain, in Auwers J-M \& Wénin A (éds.), Lectures et relectures de la Bible. Festschrift P-M Bogaert., 421-441. Leuven: Peeters.

Otto, E 1993. Art. šb $b^{c}$ in TWAT VII, 1000-1027.

Peels, H G L 1995. The Vengeance of God. The Meaning of the Root NQM and the Function of the NQM-texts in the Context of Divine Revelation in the Old Testament. OTS 31. Leiden: Brill.

-, 2006. Stem en tegenstem. Het beeld van God in de theologie van Walter Brueggemann. Theologia Reformata 49, 124-143.

Preuss, H D 1992. Theologie des Alten Testaments. Band 2: Israels Weg mit $J H W H$. Stuttgart: Kohlhammer.

Procksch, O 1913. Die Genesis. Leipzig: A. Deichertsche.

Quinones, R J 1991. The Changes of Cain. Violence and The Lost Brother in Cain and Abel Literature. Princeton: University Press.

Ross, A P 1988. Creation and Blessing. A Guide to the Study and Exposition of the Book of Genesis. Grand Rapids: Baker. 
Ruppert, L 1992. Genesis. Ein kritischer und theologischer Kommentar. 1. Teilband: Gen 1,11-11,26. Forschung zur Bibel 70. Würzburg: Echter.

Sarna, N M 1989. Genesis. JPS Torah Commentary. Philadelphia: Jewish Publication Society.

Scharbert, J 1983. Genesis 1-11. Würzburg: Echter.

Schwager, R 1978. Brauchen wir einen Sündenbock? Gewalt und Erlösung in den biblischen Schriften. München: Kösel.

Seebass, H 1996. Genesis. I: Urgeschichte (1,1-11,26). Neukirchen-Vluyn: Neukirchener.

Smelik, K 2005. Een tijd van oorlog, een tijd van vrede. Bezetting en bevrijding in de Bijbel. Zoetermeer: Boekencentrum.

Spina, F A 1992. The "Ground" for Cain's Rejection (Gen 4): "adamāh in the Context of Gen 1-11. ZAW 104, 317-332.

Van der Toorn, K, Becking, B \&Van der Horst, P 1995. Dictionary of Deities and Demons in the Bible. Brill: Leiden.

Van Wolde, E 1991. The Story of Cain and Abel: A Narrative Study. JSOT 52, 25-41.

Von Rad, G 1961. Theologie des Alten Testaments. Band 1: Die Theologie der geschichtlichen Überlieferungen Israels. München: Kaiser.

-, 1972. Das erste Buch Mose: Genesis. Das Alte Testament Deutsch. Göttingen: Vandenhoeck \& Ruprecht.

Vriezen, Th C 1974. Hoofdlijnen der Theologie van het Oude Testament. Wageningen: Veenman \& Zn.

Waltke, B K 1986. Cain and His Offering, WTJ 48, 363-372.

Wenham, G 1987. Genesis 1-15. Word Biblical Commentary 1.Waco: Word.

Westermann, C 1974. Genesis 1-11. Biblischer Kommentar Altes Testaments I/1. Neukirchen-Vluyn: Neukirchener.

Westermann, C 1978. Theologie des Alten Testaments in Grundzügen. Göttingen: Vandenhoeck \& Ruprecht.

Wils, J - P 2004. Sacraal geweld. Assen: Van Gorcum.

Wright, C J H 2004. Old Testament Ethics for the People of God. Downers Grove: InterVarsity.

Zimmerli, W 1978. Grundriss der alttestamentlichen Theologie. Stuttgart: Kohlhammer.

Zuurmond, R 1982. Het oordeel over Kain in de oud-joodse traditie. ACEBT $3,107-117$. 